\section{Evidence-based medicine and prejudice-based medicine: the case of homeopathy}

\author{
Medicina baseada em evidência e medicina \\ baseada em preconceito: o caso da homeopatia
}

Medicina basada en la evidencia y medicina
basada en el prejuicio: el caso de la homeopatía
Nelson Filice de Barros 1 Alessandra Rodrigues Fiuza 1

\footnotetext{
${ }^{1}$ Faculdade de Ciências Médicas, Universidade Estadual de Campinas, Campinas, Brasil.

Correspondence N. F. Barros

Departamento de Saúde Coletiva, Faculdade de Ciências Médicas, Universidade Estadual de Campinas.

Rua Tessália Vieira de Camargo 126, Campinas, SP 13087-887, Brasil. filice@fcm.unicamp.br
}

\begin{abstract}
In recent decades an important social movement related to Complementary and Alternative Medicine has been identified worldwide. In Brazil, although homeopathy was recognized as a specialist medical area in 1980, few medical schools offer courses related to it. In a previous study, 176 resident doctors at the University of Campinas Medical School were interviewed and 86 (49\%) rejected homeopathy as a subject in the core medical curriculum. Thus, this qualitative study was conducted to understand their reasons for refusing. 20 residents from 15 different specialist areas were interviewed. Very few of them admitted to a lack of knowledge for making a judgment about homeopathy; none of them made a conscientious objection to it; and the majority demonstrated prejudice, affirming that there is not enough scientific evidence to support homeopathy, defending their position based on personal opinion, limited clinical practice and on information circulated in the mass media. Finally, resident doctors' prejudices against homeopathy can be extended to practices other than allopathic medicine.
\end{abstract}

Evidence-Based Medicine; Complementary Therapies; Homeopathy; Prejudice

\section{Resumen}

Durante as últimas décadas, um importante movimento social relacionado à Medicina Alternativa e Complementar foi identificado em todo o mundo. No Brasil, apesar de a homeopatia ser reconhecida como especialidade médica desde 1980, poucas escolas médicas oferecem cursos relacionados a ela. Em um estudo prévio, 176 médicos residentes da Faculdade de Medicina da Universidade Estadual de Campinas foram entrevistados e 86 (49\%) recusaram a disciplina de homeopatia no currículo médico. Portanto, este estudo qualitativo foi conduzido para entender as razões desta recusa. Vinte residentes de 15 especialidades diferentes foram entrevistados. Poucos declararam falta de conhecimento para julgar a homeopatia; nenhum deles fez uma objeção consciente a ela; e a maioria demonstrou preconceito, afirmando que não há evidência científica suficiente para sustentá-la, defendendo suas posições baseados em opinião pessoal, prática clínica limitada e em informações de meios de comunicação de massa. Finalmente, este preconceito em relação à homeopatia pode ser estendido a outras práticas diferentes da medicina alopática.

Medicina Baseada em Evidências; Terapias Complementares; Homeopatia; Preconceito 


\section{Introduction}

The indexed literature on Complementary and Alternative Medicine (CAM) has had around two hundred new clinical studies per annum added to it, leading to a considerable increase in the availability of evidence about its use 1 . Nevertheless, different biases related to the process of disseminating this knowledge have also been observed, such as the so called bias of localization 2 , which shows that the greater part of positive evidences on the use of CAM are published in no- or low-impact-factor journals. In addition there is the geographic bias 3 , which shows high impact North American journals tend to publish more negative evidence, while European journals, which also have a high impact factor, tend to publish a greater number of studies with positive evidence.

These biases certainly matter a great deal as regards the introduction of CAM in national health systems, as professionals, health policy managers and constructors tend to keep up to date by seeking journals of greater impact, exactly those in which the majority of negative evidences are published 4 . This is one way of explaining the perpetuation of the cycle of rejection and social nonexistence of CAM, which can be identified within a system of maintaining the status quo composed of the pressures of the monoculture of knowledge, linear time, naturalization of differences, logic of the dominant and logic of productivity 5 .

To gain a better understanding of the structure of this complex, Polich et al. 6 interviewed researchers of outstanding importance to identify how they perceive and negotiate the challenges of research with CAM in the area of health. After analyzing the history of personal engagement of these researchers, their reactions to the strategies for disseminating their studies in peer reviewed journals, they concluded that these investigators are exposed to constant pressures to appear and act in a more "scientific" way.

Different studies have been conducted with medical students and resident doctors including on issues such as their perceptions and use of CAM. According to Teixeira et al. 7, over $85 \%$ of the medical students at the University of São Paulo considered that homeopathy and acupuncture should be included in curricula, as options (72\%) or compulsorily (19\%); while $56 \%$ showed a great interest in learning about them. In another study conducted during a medical students' conference, Teixeira 8 found that $43 \%$ of students did not recognize homeopathy as a "medical specialty", they were all unaware that it was "available through public health services" 8 (p. 16) and 64\% did not know about its "inclusion in the curriculum of some Brazilian Medical Schools” 8(p. 16). According to Soledad et al. 9, only $40 \%$ (99) of 247 medical students, from the University of Campinas, correctly answered the questions about homeopathy principles and $25 \%$ of them were completely incorrect in their answers.

With regard to resident doctors, Brotherton et al. 10 found that a quarter of the medical residence programs in the United States develop subjects and practices associated with CAM. It was also pointed out by Lebensohn et al. 11 and Maizes et al. 12 that the offer of these subjects in family medicine programs have overcome the lack of interest of young professionals in this area, leading to an increase in demand. This fact was considered absolutely pertinent by Frenkel et al. 13 due to the proximity of the type and manner of work of the family health doctor and CAM.

Other studies with resident doctors investigated specific knowledge and attitudes. The findings of Ashar et al. 14 showed that residents from 15 different internal medicine programs in the United States had little knowledge about the use, efficacy, safety and drug interaction of vitamin supplements. Very similar results were obtained by $\mathrm{Xu} \&$ Levine 15 as regards the use of phytotherapeutic medications, especially with respect to the knowledge necessary for prescribing and referring patients to other professionals. Another interesting finding described by Lie \& Boker 16 was that in comparison with professors and undergraduate students, the group of resident doctors at the Irvine School of Medicine of the University of California is the group that makes least use of practices such as: meditation, tai chi, herbs, vitamins and homeopathy.

The issue at stake is the reconfiguration of the frontiers of biomedicine and what are seen as important actions of advancement and retrocession that extrapolate the dominions of scientific knowledge. This movement confirms the theory of Marcuse 17 and Denzin 18 that against an action of counterculture, there is a cultural backlash, so that people with new ideas are sometimes rejected outright, whether or not there is evidence to support their point of view.

Based on this set of information, a qualitative project was conducted with resident doctors from one of the most important Medical Schools in Brazil, about their perceptions related to learning homeopathy as part of medical undergraduate studies. 


\section{Methodology}

In a previous quantitative cross-sectional study developed in 2008, 86 (48.9\%) of the total of 176 resident doctors were unfavorable to the inclusion of homeopathy in the undergraduate curriculum 19. In 2010 we developed a qualitative study $20,21,22$ in which 20 resident doctors were interviewed using semi-structured interview techniques, out of the 23 who were still in medical residence programs at the School of Medical Sciences, University of Campinas (FCM/UNICAMP).

The participating residents were from 15 different residence programs, namely: Gynecology and Obstetrics; Nephrology; Dermatology; Cardiology; Radiology and Imaging Diagnosis; Ophthalmology; Otorhinolaryngology; Infectology; Orthopedics and Traumatology; Plastic Surgery; Pediatrics (Pediatric Nephrology); Anesthesiology; Urology; Psychiatry; and Radiotherapy.

Their demographic characteristics were: $47.37 \%$ female and $52.63 \%$ male; age-range 26 to 31 years and conclusion of medical course between 2002 and 2007. The majority concluded their undergraduate studies at the FCM/UNICAMP.

The participants were invited to respond voluntarily to the research, after being informed of its objectives. Each resident was contacted personally, and signed the Informed Consent Form. The interviews were of a short duration, in spite of the interviewers' strategy of posing direct questions in an endeavor to encourage participants to talk 22 . In some interviews, irritability was perceived when the participant's position was being questioned. However other resident doctors changed their opinions as regards the inclusion of homeopathy in undergraduate courses, perhaps as a result of the effect of the research, while demonstrated an interest in talking more about the subject after the interviews, both to clear up doubts and to find out the interviewer's opinion, or even to expand on their own interviews. The interviews were recorded, transcribed and analyzed by the second author and checked by the first. Data analysis was thematic, fulfilling the stages of classification by theme and deductive categorization.

The study was conducted in accordance with the Helsinki Declaration, Resolution n. 196/1996 and Resolution n. 466/2012 (Brazilian National Health Council), and was approved by the Ethics Research Committee of UNICAMP (report $n$. 136/2010).

\section{Results}

None of the interviews refused homeopathy based on conscientious objection, since no argument presented was of an informed nature on the principles of homeopathy, and the justifications were based on general concepts and common sense. Thus, the interviewees made objections to homeopathy without knowledge of it and without producing an epistemological rupture, which goes beyond the spontaneous perspective of the production of knowledge.

In the 20 interviews held, there were few expressions of a lack of knowledge and it is not possible to affirm that this is the most relevant factor in their justifications. Moreover, a strong relationship was observed between a lack of knowledge and negative social value relative to homeopathy practices. The first association can be observed in the following extract, in which the interviewee affirms not having a great deal of knowledge about homeopathy, and even so, does not give it any credit.

"In truth I do not know a great deal in order to have something to say. It's as I told you, one has no basis. One has the idea that homeopathy is a lot of little drops, natural things or not, but in truth, one is not in the habit of giving a lot of credit to the pharmacological part of the stuff, you see?" (R1).

The lack of knowledge and negative value is no different in the extract below, however in it one observes an aspect associated with hardly reflexive social reproduction and a biased basis. Thus, even among those who sought to be coherent, affirming they do not know homeopathy, their arguments allowed them to see the negative social value.

"In truth, I don't think I have a great deal of argument to talk about this, because I have never studied it in depth. Homeopathy is a course we do not have in undergraduation, so, after all, I don't have sufficient knowledge to be saying this. What I know about homeopathy, I sincerely do not believe. From what I know, I really don't believe" (R2).

In the material analyzed here, prejudice was expressed in different forms, delimiting a set of sub-themes related to gender, ethnicity, social class and other forms. In the following extract when the resident doctor was invited to explain his point of view, he justified it on the basis of evidence-based practice, but when he was asked to discuss his evidence, then it was characterized as prejudice, as can be observed.

(I): "In the research last year, you said that homeopathy should not be introduced in the undergraduate course, why?".

(P): "Because I think there is not a lot of scientific evidence, therefore it should not be taught". 
(I): "Based on what evidence did you identify this negative point of homeopathy?".

(P): "It is because what I know about homeopathy it does not have.... It is that I... homeopathy starts from this principle of dividing something in several, several a several times, dilution, is it not so?? Now, I confess, I never studied it properly to know" (R4).

Another subtheme used to justify the position against homeopathy was associated to clinical experience. It is well known that this is one of the pillars of medical education, however the defense based on clinical practice is a little premature in this case, since it concerns recently graduated resident doctors.

(I): "In the research last year, you said that homeopathy should not be introduced in the undergraduate course, why?".

(P) "Because I don't believe in the theory of homeopathy".

(I): "Based on what evidence?".

(P): "Based on clinical practice. (...) I have never sat down to read a study... I have heard comments about studies that have been made and they have never managed to prove the efficacy of homeopathic medication. I have never taken a study to read and have never even been interested in looking for one" (R3).

Of the same order as the justification in which clinical experience is given, there is personal experience. This justification is also poorly based and in the citation below, it is less clear than ever, since one is unable to identify whether the experience is of personal use of homeopathy or that of patients that are treated.

(I): "In the research last year, you said that homeopathy should not be introduced in the undergraduate course, why?".

(P): "Because I think it doesn't have a very broad scientific basis".

(I): "Are you basing this on some evidence to identify this point?".

(P): "Personal experience only, no scientific evidence, nothing like that. Personal experience, of my patients" (R12).

Another theme that characterizes prejudice is associated with the reproduction of information circulated by the mass media, whose validation criteria are not exactly based on scientific evidence. The first extract, justifying on the basis of a television program, presents homeopathy firstly as an "alternative therapy", something that was very common in academic debates in the 1970s and $80 \mathrm{~s}$. The second segment of the interview reproduces information that a large British journal published and which was circulated on the Internet, also with poor criterial details. However, what draws most attention in this speech is the warning the interviewee gives the researcher on dealing with a practice that could lead to "being put in jail!", as can be observed as follows.

(I): "In the research last year, you said that homeopathy should not be introduced in the undergraduate course, why?".

(P): "Because I think it is an alternative therapy, not so? There are no studies as yet proving the efficacy of homeopathy, there are still many questions about homeopathy that does not make it a therapy that is applied to all patients".

(I): "Do you base this on some evidence?".

(P): "On what one sees, in reports, on television about homeopathy, there was even that report that came out on "Fantástico", that homeopathy was not effective" (R18).

(I): "In the research last year, you said that homeopathy should not be introduced in the undergraduate course, why?".

(P): "Because it has no scientific basis, or scientific proof that it works".

(I): "Based on what evidence did you identify this negative point of homeopathy?".

(P): "Recently there was the child of a homeopathic doctor in Australia, who died because he was a homeopath and refused to treat the child with conventional treatment. He was condemned, put in jail! For not having treated his child adequately. (...) I don't believe it forms part of the scope of medical sciences" (R7).

The last theme is associated with the social invisibility of this medicine in comparison with hegemonic practice. This is a strong expression of the "monoculture of knowledge" which produces insignificance, promoting non existence. So that those who opt to treat or to be treated with homeopathy do not exist and it is not even necessary to have any evidence to prove this "secondary subarea", as is observed in the following segment.

(I): "In the research last year, you said that homeopathy should not be introduced in the undergraduate course, why?".

(P): "And I think that in the face of the necessity, amount of knowledge, I would see this subarea as secondary in comparison with the others".

(I): "And to you, which is the most negative aspect of homeopathy?".

(P): "I think the lack of evident and clear bases of its results".

(I): "Do you base this on some evidence?".

(P): “No" (R1).

Thus, it is showed that prejudice appears to be the basis for medical residents' refusal of homeopathy. A fact that prevents them from seeking greater knowledge and studying it, based on their denial essentially of the mistaken nonexistence of scientific evidences, proof on the 
bases of personal experience, reproduction of scarcely accurate information circulated in the mass media and the invisibility of this practice in comparison with the hegemonic model. Certainly, the result is the maintenance of the cycle of prejudice in which doctors, by denying it, do not know it, and because they do not recognize it, they deny it.

\section{Discussion}

It should be pointed out that there were some difficulties in performing the work of data collection, such as: (a) finding the interviewees, who frequently change training section within the Medical School Hospital complex; (b) little availability of the resident doctors due to the great demand for them; (c) resident doctors' low level of interest in this subject. Nevertheless, we inferred that two points helped in promoting receptiveness to participation in the research: (a) recognition of the interviewer due to having conducted the previous study; and (b) appreciation of the importance of scientific research to the academic life of the interviewees 19 .

This study has the limitation of being developed in only one medical school; however it is one of the most important schools of medicine in Brazil. Also, the multi-method perspective adds credibility to the study 22 .

Homeopathic medicine was introduced to Brazil in the XIX century and is currently ranked the 16th medical specialty with the largest contingent of professionals among 61 specialties analyzed in the survey conducted in 1996 7,8,23. Nevertheless, only 17 schools of medicine among 115 analyzed in Brazil have been teaching homeopathic principles, and among these not all respect the minimum curriculum of 45 minutes per lesson as suggested by the Brazilian Homeopathic Medical Association 24.

In this article, the idea that CAM should be used by all and for all health problems is not defended, but that professionals should know its principles and discuss their decision based on well founded evidence and conscientious approval or objection, and not on a lack of knowledge or prejudice.

Conscientious objection was considered the argument that lets one see that the individual refuses to practice or act on the basis of moral judgment, in accordance with philosophical, religious or political beliefs. It is a concept of the same order as that of "civil disobedience", whereby some soldiers refused to take part in the war. Later, this concept was brought to the medical field, mainly associated with debates on medical ethics, relative to abortion and euthanasia 25,26.

For Gampel 27, there are five factors that justify conscientious objection in medicine: (1) the centrality for the doctor's essential ethical values; (2) the basic rules of the profession and relevance to the moral integrity of the professional doctor; (3) the instruction of the concept of the doctor as a medical ethic, rather than a personal ethic; (4) the impact on the rights and interests of patients; and (5) recognition of the competent rights and interests by law and by the rules of medical ethics.

It was considered a lack of knowledge when perceptions related to the following factors could be observed in the discourses: ignorance resulting from not reading, lack of knowledge, information, or education about homeopathy; lack of experience and the knowledge/understanding derived from self experience and other experience with homeopathy; lack of understanding, unfamiliarity with, innocence of, unconsciousness of homeopathy bases 28 . Prejudice is understood as generalizations expressed from personal experience or by imposition from the social medium, showing one to be against the practice, fact, or person, before even getting to know it. As in other expressions of prejudice, in this analysis one can also observe justifications that are inadequate from the point of view of knowledge, not very accurate and expressions of resistance on a non rational basis.

The majority of the professionals interviewed are recently qualified doctors with little practice and knowledge about homeopathy and in their school experiences they take on prejudices without realizing they are reproducing it. In fact, they carry out an action that has already become well known, and which only varies in relation to the object, because prejudice is not something that experience accumulates and that guides the action without blocking reflection. Prejudice is constructed and involves generalization to all elements that form part of a set of characteristics that do not necessarily belong to the object. Thus, prejudice is not a cognitive process, but it is its negation; and it is not even the exercise of free imagination, because the petrified subjectivity in prejudice prevents freedom 29 .

The resident doctors interviewed refused homeopathy based on the movement of Evidence Based Medicine (EBM). This finding is recurrent among allopathic doctors and coherent with the analyses presented in other articles 4,30 . The adoption of EBM makes it possible to see that it deals with an action that precedes "prejudice", supported by stereotyped thinking. For Jahoda \& Ackerman 31 it concerns an attitude of hostility 
in interpersonal relationship, directed against an entire group or against individuals belonging to it and which is an irrational purpose.

Prejudice as it has been identified does not point towards a process of conception, or to singularization of the type of evidence lacking, but rather to the production of social invisibility. Indeed, more knowledge about homeopathy is necessary, however a meta-analysis was developed at the beginning of the 1990s, constructed with 105 controlled clinical studies, among which 81 pointed to the positive effects of homeopathy and 24 to negative effects 32 .

Thus, an exercise of visibility is necessary, on the one hand to reflect on the biases of studies about CAM published in conventional medical journals, and on the other hand, broaden the perspective of science in the field of health, with a process of observation, identification, description, experimental investigation and theoretical discussion, not restricted to a single tradition of thought. It is possible to identify the smaller number of publications about CAM in journals with a high impact factor owing to: (a) low inclusion of professionals practicing CAM in the academic environment, which may lead to less scientific training; (b) lack of adequate financing, due not only to distancing from academia, but mainly to a lack of interest on the part of supporting institutions; and (c) a lack of cooperation between biomedical researchers and CAM 33 .

The invisibility of CAM is prejudicial not only to scientific knowledge, but also to patients, who frequently do not reveal the other forms of care and cure they use, assuming the risks with the purpose of not exposing themselves to further social humiliation. Solely accepting the onus for the non conventional therapeutic option can also be understood as resistance against the reification or even genesis of its pathogenesis; or surrender to a fixed enunciation, "reified" and transformed into a fetish 34 .

This is why the World Health Organization 35 has created proposals for social inclusion of non conventional practices that guarantee access to other forms of understanding the health-diseasecare process; to help the dialogue between biomedical professionals and practitioners of CAM; to regulate the practice of CAM and promote its implementation in health systems with safe and rational use. In the United States, different approaches have been taken to implement CAM in health services 36 and to teach in the field of health ${ }^{37}$. In Brazil the pathways are different, because homeopathy has been a medical specialty for more than 30 years, and it is being included in the Brazilian Unified National Health System and some Brazilian medical schools 24,38.
The actions of the WHO and its affiliates promote social inclusion and limit prejudice. In this way, one does not seek to exonerate the agent from responsibility for his acts, but understand the genesis of his action in a culture that privileges force and in which the prejudiced individual prepares the action of exclusion of those who are weaker by those who cannot live with their own fragility 39. Therefore, inclusion of CAM in undergraduate courses in the field of health is fundamental so that students have information and education and can operate as agents of social transformation 40 .

From this general panorama it is possible to see the marginalization of homeopathy and the challenges of connivance with differences in teaching and medical assistance; as well as the construction of social environments that allow the coexistence of traditions, founded on different principles or visions which may help in the processes of prevention and health promotion 10 . On the other hand, it points to the need for the development of the sociology of CAM, based on therapeutic pluralism ${ }^{41}$.

\section{Final considerations}

In this article a critical perspective has been adopted to analyze the evidence in the field of health as a fact that expresses domination, prejudice, and the mistaken use of a tool. Nevertheless, the epistemic guidance adopted is the same that Foucault 42 (p. XVI) announced in the introduction of the Birth of the Clinic: "This book is not written by one medicine against another, or against medicine, by an absence of medicine. Here, as in other places, it deals with a study that tries to extract from the thickness of the discourse, the conditions of its history. What counts in the things said by men is not so much what they have thought short of or beyond them, but what has systematized them from the beginning, making them, throughout time, infinitely accessible to new and open discourses to the task of transforming them".

Therefore, there is no pretension to affirm that one practice has greater relevance than another, or to follow with alternative guidance of the counterculture of the 1960s and 1970s, but to give visibility to a clash within the field of health. However, it is concluded that prejudice is still one of the main constraints to the inclusion of alternative and complementary medicines in academic undergraduate courses in medicine. This involves the creation of a vicious cycle of refusal, based on biases that produce invisibility, exclusion and social humiliation for those who use it, in the condition of professional or patient. 
Based on the reproduction of irrational concepts and backed by the discourse of evidencebased medicine, the resident doctors interviewed have shared prejudices against homeopathy. Thus, they demand scientific evidence for recognition, but not for refusing, which shows a clear contradiction between an evidence-based discourse and a practice based on prejudice. In the face of this scenario, the need for the inclusion of non conventional care and cure practices in undergraduate courses is preeminent, in order to guarantee, based on the thinking of social conditions that promote inclusion and help to combat subjective conditions related to prejudice.

Finally, it is concluded that in the last few decades an important social movement has occurred related to the non biomedical care practices in the field of health, starting with a contradiction that still persists: never have we had so much diagnostic and predictive capacity in western medicine, however, there has also never before been a record of such quest for practices of other types of medicines.

Nevertheless, it is necessary to observe qualitative changes within this contradiction over the last few decades, as CAM have moved from the marginality of the field of health to its periphery 43. This movement must be appreciated and recognized, for example, in the fact that $51 \%$ (90) of resident doctors interviewed accepted and supported the teaching of homeopathy in the medical course. Undoubtedly this is a significant advance of non conventional practices in the field of health, demonstrating that although there is hegemony in the biomedical model in this field, its structure is not entirely equal or homogeneous.

\section{Resumen}

Durante las últimas décadas, un importante movimiento social relacionado con la medicina alternativa y complementaria ha surgido en todo el mundo. En Brasil, pese a que la homeopatía fue reconocida como especialidad médica desde 1980, pocas escuelas médicas ofrecen cursos. En un estudio previo, 176 médicos residentes de la Universidad de Campinas- Facultad de Medicina fueron entrevistados y 86 (49\%) rechazaron el curso de homeopatía en el plan de estudios médicos. Este estudio cualitativo se propone entender las razones del rechazo. Se entrevistaron a veinte residentes de 15 especialidades diferentes. Pocos declararon falta de conocimientos para juzgar la homeopatía; ninguno hizo una objeción consciente a la misma; y la mayoria demostró prejuicios, afirmando que no hay evidencia científica que apoye la homeopatía, defendiendo sus posiciones con opinión personal, práctica clínica limitada e informaciones de medios de comunicación de masas. Finalmente, el prejuicio de los médicos residentes sobre la homeopatía se puede extender a otras prácticas diferentes de la medicina alopática.

Medicina Basada em Evidencia; Terapias

Complementarias; Homeopatía; Prejuicio

\section{Contributors}

N. F. Barros and A. R. Fiuza were responsible for the project and writing the paper.

\section{Acknowledgments}

The authors would like to thank the referee for important suggestions. 


\section{References}

1. Ernst E. The fascination of complementary and alternative medicine (CAM). J Health Psychol 2007; 12:868-70.

2. Pittler MH, Abbot NC, Harkness EF, Ernst E. Location bias in controlled clinical trials of complementary/alternative therapies. J Clin Epidemiol 2000; 53:485-9.

3. Sood A, Knudsen K, Sood R, Wahner-Roedler DL, Barnes SA, Bardia A, et al. Publication bias for CAM trials in the highest impact factor medicine journals is partly due to geographical bias. J Clin Epidemiol 2007; 60:1123-6.

4. Sierpina VS, Kreitzer MJ. The continuing bias against complementary and integrative healthcare education. Explore (NY) 2010; 6:54-6.

5. Santos BS. Conhecimento prudente para uma vida decente. São Paulo: Editora Cortez; 2004.

6. Polich G, Dole C, Kaptchuk TJ. The need to act a little more 'scientific': biomedical researchers investigating complementary and alternative medicine. Sociol Health Illn 2010; 32:106-22.

7. Teixeira MZ, Chin AL, Martins MA. Homeopathy and acupuncture teaching at Faculdade de Medicina da Universidade de São Paulo: the undergraduates attitudes. São Paulo Med J 2005; 123:77-82.

8. Teixeira MZ. Homeopatia: desinformação e preconceito no ensino médico. Rev Bras Educ Med 2007; 31:15-20.

9. Soledad GNB, Sigel P, Barros NF. Educação médica e práticas não convencionais em saúde: análise do nível de informação de acadêmicos de medicina sobre a homeopatia. In: Barros NF, Siegel P, Otani MAP, editors. $\mathrm{O}$ ensino de práticas integrativas e complementares: experiências e percepções. São Paulo: Editora Hucitec; 2011. p. 99-113.

10. Brotherton SE, Rockey PH, Etzel SI. US graduate medical education, 2003-2004. JAMA 2004; 292: 1032-7.

11. Lebensohn P, Campos-Outcalt D, Senf J, Pugno PA. Experience with an optional 4-year residency: the University of Arizona Family Medicine Residency. Fam Med 2007; 39:488-94.

12. Maizes V, Silverman H, Lebensohn P, Koithan M, Kligler B, Rakel D, et al. The integrative family medicine program: an innovation in residency education. Acad Med 2006; 81:583-9.

13. Frenkel M, Ben-Arye E, Hermoni D. An approach to educating family practice residents and family physicians about complementary and alternative medicine. Complement Ther Med 2004; 12:118-25.

14. Ashar BH, Rice TN, Sisson SD. Medical residents' knowledge of dietary supplements. South Med J 2008; 101:996-1000.

15. Xu S, Levine M. Medical residents' and students attitudes towards herbal medicines: a pilot study. Can J Clin Pharmacol 2008; 15:1-4.

16. Lie DA, Boker J. Comparative survey of Complementary and Alternative Medicine (CAM) attitudes, use, and information-seeking behaviour among medical students, residents \& faculty. BMC Med Educ 2006; 6:58

17. Marcuse H. O fim da utopia. Rio de Janeiro: Paz e Terra; 1969.
18. Denzin NK. The qualitative manifesto: a call to arms. Walnut Creek: Left Coast Press Inc.; 2010.

19. Fiuza AR, Otani MAP, Barros NF. A homeopatia e o ensino médico de graduação e residência. In: Barros NF, Siegel P, Otani MAP, editors. O ensino de práticas integrativas e complementares: experiências e percepções. São Paulo: Editora Hucitec; 2011. p. 114-27.

20. Broom A. Using qualitative interviews in CAM research: a guide to study design, data collection and data analysis. Complement Ther Med 2005; 13: 65-73.

21. Ulin PR, Robinson ET, Tolley EE. Investigación aplicada en salud pública: métodos cualitativos. Rev Inst Med Trop São Paulo 2007; 49:86.

22. Pope $\mathrm{C}$, Mays N. Pesquisa qualitativa na atenção à saúde. Porto Alegre: Editora Artmed; 2009.

23. Teixeira M Z. Panorama da pesquisa em homeopatia: iniciativas, dificuldades e propostas. Diagn Tratamento 2004; 9:98-104.

24. Salles SAC. A presença da homeopatia nas faculdades de medicina brasileiras: resultados de uma investigação exploratória. Rev Bras Educ Méd 2008 32:283-90.

25. Frader J, Bosk CL. The personal is political, the professional is not: conscientious objection to obtaining/providing/acting on genetic information. Am J Med Genet C Semin Med Genet 2009; 151C:62-7.

26. Wicclair MR. Conscientious objection in medicine. Bioethics 2000; 14:205-27.

27. Gampel E. Does professional autonomy protect medical futility judgments? Bioethics 2006; 20: 92-104.

28. Babylon Dictionary. http://educacao.uol.com.br/ dicionarios/ (accessed on 31/Jul/2014).

29. Adorno TW. Consignas. Buenos Aires: Amorrotu; 1972.

30. Milgrom LR. The eternal closure of the biased mind? the clinical and scientific relevance of biophysics, infinitesimal dilutions, and the memory of water. J Altern Complement Med 2009; 15: 1255-7.

31. Jahoda M, Ackerman NW. Distúrbios emocionais e anti-semitismo. São Paulo: Editora Perspectiva; 1969.

32. Kleijnen J, Knipschild P, Ter Riet G. Clinical trials of homoeopathy. BMJ 1991; 302:316-23.

33. Eskinazi D, Muehsam D. Is the scientific publishing of complementary and alternative medicine objective? J Altern Complement Med 1999; 5: 587-94.

34. Adorno TW, Horkheimer M. Temas básicos de sociologia. São Paulo: Cultrix; 1973

35. World Health Organization. Tradicional medicine strategy: 2002-2005. Geneva: World Health Organization; 2002.

36. Josefek KJK. Alternative medicine's roadmap to mainstream. Am J Law Med 2000; 26:295-310.

37. Consortium of Academic Health Centers for Integrative Medicine. http://www.imconsortium.org/ (accessed on 31/Jul/2014). 
38. Ministério da Saúde. Política Nacional de Práticas Integrativas e Complementares no SUS - PNPICSUS. Brasília: Ministério da Saúde; 2006.

39. Crochik JL. Preconceito - indivíduo e cultura. São Paulo: Robe Editorial; 1997.

40. Frenk J, Chen L, Bhutta ZA, Cohen J, Crisp N, Evans T, et al. Health professionals for a new century: transforming education to strengthen health systems in an interdependent world. Lancet 2010; 376:1923-58.

41. Broom A, Tovey P. Therapeutic pluralism - exploring the experiences of cancer patients and professionals. London/New York: Routledge; 2008
42. Foucault M. O nascimento da clínica. 5a Ed. Rio de Janeiro: Forense Universitária; 1988.

43. Luz MT, Barros NF. Racionalidades médicas e práticas integrativas em saúde: uma análise sócio-histórica e suas relações com a cultura atual. In: Campos GWS, Bonfim JRA, Minayo MCS, Akerman M, Drumond Júnior M, Carvalho YM, editors. Tratado de saúde coletiva. 2a Ed. São Paulo: Editora Hucitec; 2013. p. 317-40.

Submitted on $24 /$ Oct/2013

Final version resubmitted on 11/Apr/2014

Approved on 12/May/2014 